\title{
$\gamma$-Aminobutyric acid production by selected lactic acid bacteria isolate of an Indonesian indigenous fermented buffalo milk (dadih) origin
}

\author{
Harnentis Harnentis ${ }^{1}$, Nurmiati Nurmiati ${ }^{2}$, Yetti Marlida ${ }^{1}$, Frederick Adzitey ${ }^{3}$ and Nurul Huda ${ }^{4}$
}

1. Department of Animal Nutrition and Feed Technology, Faculty of Animal Science, Andalas University, West Sumatera, Indonesia; 2. Department of Biology, Faculty of Natural Sciences, Andalas University, West Sumatera, Indonesia;

3. Department of Veterinary Science, Faculty of Agriculture, University for Development Studies, Box TL 1882, Tamale, Ghana; 4. Department of Food Science, Faculty of Food Science and Nutrition, Universiti Malaysia Sabah, Kota Kinabalu, Sabah, Malaysia.

Corresponding author: Yetti Marlida, e-mail: yettimarlida@ansci.unand.ac.id

Co-authors: HH: harnentis@ansci.unand.ac.id, NN: nurmiati@fmipa.unand.ac.id, FA: adzitey@yahoo.co.uk, $\mathrm{NH}$ : drnurulhuda@ums.edu.my

Received: 17-03-2019, Accepted: 17-07-2019, Published online: 30-08-2019

doi: 10.14202/vetworld.2019.1352-1357 How to cite this article: Harnentis $H$, Nurmiati N, Marlida Y, Adzitey F, Huda N (2019) $\gamma$-Aminobutyric acid production by selected lactic acid bacteria isolate of an Indonesian indigenous fermented buffalo milk (dadih) origin, Veterinary World, 12(8): 1352-1357.

\begin{abstract}
Aim: This study aimed at optimizing $\gamma$-aminobutyric acid (GABA) production using lactic acid bacteria (LAB) of an Indonesian indigenous fermented buffalo milk (dadih) origin. This study utilized LAB previously cultured from dadih that has the ability to produce GABA.
\end{abstract}

Materials and Methods: The study started with the identification of selected LAB by 16S rRNA, followed by optimization of GABA production by culture conditions using different initial $\mathrm{pH}$, temperature, glutamate concentration, incubation time, carbon, and nitrogen sources. 16S rRNA polymerase chain reaction and analysis by phylogenetic were used to identify Lactobacillus plantarum (coded as N5) responsible for the production of GABA.

Results: GABA production by high-performance liquid chromatography was highest at $\mathrm{pH}$ of 5.5 , temperature of $36^{\circ} \mathrm{C}$, glutamate concentration of $500 \mathrm{mM}$, and incubation time of $84 \mathrm{~h}$. Peptone and glucose served as the nitrogen and carbon sources, respectively, whereas GABA was produced at optimum fermentation condition of $211.169 \mathrm{mM}$.

Conclusion: Production of GABA by L. plantarum N5 was influenced by initial pH of 5.5, glutamic acid concentration, nitrogen source, glucose as carbon source, and incubation temperature and time.

Keywords: fermented buffalo milk, Indonesian indigenous product, lactic acid bacteria, $\gamma$-aminobutyric acid.

\section{Introduction}

Indigenous fermented buffalo milk, locally known as dadih, is an essential food source for the populace of West Sumatera, Jambi, and Riau of Indonesia. Putra et al. [1] indicated that dadih is an important diet and consumed largely by people of West Sumatera and Minangkabau. Microflora of dadih are essential for their role in fermentation (aroma, texture, and acidity), therapeutic (improves digestion), and antimicrobial activity [2]. Dadih generally can be consumed directly or with rice. At first glance, this food seems unfamiliar to some Indonesian people. Dadih itself comes from buffalo milk which is kept in bamboo and covered using banana leaves. It is then allowed to stand at room temperature for a day to form clots. According to Surono [3], clumping occurs due to the presence of microbes derived from bamboo and banana leaves so that it will produce a form

Copyright: Harnentis, et al. Open Access. This article is distributed under the terms of the Creative Commons Attribution 4.0 International License (http://creativecommons.org/licenses/ by/4.0/), which permits unrestricted use, distribution, and reproduction in any medium, provided you give appropriate credit to the original author(s) and the source, provide a link to the Creative Commons license, and indicate if changes were made. The Creative Commons Public Domain Dedication waiver (http:// creativecommons.org/publicdomain/zero/1.0/) applies to the data made available in this article, unless otherwise stated. that is clad and yellowish-white and has a distinctive aroma. Pato [4] stated that dadih contains high protein $(39.8 \%)$ with complete essential amino acids, calcium, Vitamin B, and Vitamin K which are formed during the fermentation process. In addition, bacteria in dadih are capable of inhibiting intestinal pathogens and thus can help facilitate digestion. Nowadays, interest in indigenous fermented buffalo milk and microflora is increasing, especially in the production of metabolites that can be used as food or feed additive, such as $\gamma$-aminobutyric acid (GABA).

Lactic acid bacteria (LAB) such as Lactobacillus plantarum, Lactobacillus brevis, Streptococcus agalactiae, Bacillus cereus, Streptococcus uberis [5], and L. plantarum [6] have been isolated from dadih. Surono [3] also reported the isolation of LAB such as Lactococcus lactis, L. brevis, Lactococcus casei, $L$. plantarum, E. faecium, and Leuconostoc mesenteroides from dadih. Functional compounds such as peptides and oligosaccharides together with lactic acid are produced when LAB are used to ferment foods. In addition, functional compounds like GABA (a non-protein amino acid) functions as neurotransmitter inhibitor and exhibit hypotensivity [7]. GABA is one of the most important functional components in fermented foods due to its physiological functions such as 
neurotransmission and antihypertensive activities [8], and anti-heat stress for broilers [9]. Nonetheless not much is known about GABA-rich fermented foods that can be used as feed additives. GABA production by microbes is affected by factors such as initial $\mathrm{pH}$, fermentation time, medium composition, glutamate concentration, and temperature $[7,8]$. Li et al. [10] added that the highest GABA production by L. brevis was achieved at optimum $\mathrm{pH}$ of 5.0. Komatsuzaki et al. [11] found the optimum GABA production at $500 \mathrm{mM}$ glutamate content in culture media of Lactobacillus paracasei NFRI 7415. Yang et al. [12] reported that optimizing fermentation conditions to a $\mathrm{pH}$ of 4.5 resulted in an improved GABA production in Streptococcus salivarius culture.

This study was conducted to improve the production of GABA by selected LAB that were isolated from indigenous fermented buffalo milk (dadih) through optimization of fermentation parameters such as initial $\mathrm{pH}$, temperature, glutamate concentration, incubation time, carbon, and nitrogen sources.

\section{Materials and Methods}

Ethical approval

No human or animal objects were used; therefore ethical approval was not sought.

\section{Isolation of LAB}

The LAB strains used were obtained from indigenous fermented buffalo milk (dadih) in West Sumatera region, Indonesia [13].

\section{Identification of LAB by $16 S$ rRNA}

Identification of LAB by $16 \mathrm{~S}$ rRNA was done using 63 F: 5'-CAG GCC TAA CAC ATG CAA GTC-3' and 1387 R: 5'-GGG CGG GGT GTA CAA GGC-3'. An approximately $1.5 \mathrm{~kb}$ fragment was amplified in a Biometra's T-Personal Thermal Cycler, USA. The polymerase chain reaction (PCR) conditions were as follows: Initial denaturation at $95^{\circ} \mathrm{C}$ for $5 \mathrm{~min}$, followed by 35 cycles of denaturation at $94^{\circ} \mathrm{C}$ for $1 \mathrm{~min}$, annealing at $56^{\circ} \mathrm{C}$ for $1 \mathrm{~min}$, and a final extension at $72^{\circ} \mathrm{C}$ for $1.5 \mathrm{~min}$. The PCR products were analyzed on $1.0 \%(\mathrm{w} / \mathrm{v})$ agarose gel electrophoresis (Mupid-Exu Submarine Electrophoresis System, Advance) in $1 \times$ tris-acetate-EDTA buffer at $100 \mathrm{~V}$ for $30 \mathrm{~min}$. It was visualized on a gel documentation system (Biodoc Analyze, Biometra, USA). Purified PCR products were sequenced with $16 \mathrm{~S}$ rRNA primers. Sequences of the whole gene fragment were used for similarity search against NCBI GenBank database using the Basic Local Alignment Search Tool (BLAST) program available at website http://blast. ncbi.nlm.nih.gov/Blast.cgi.

\section{Selection of LAB-producing GABA}

The previous study by Marlida et al. [13] found a sum of $10 \mathrm{LAB}$ of dadih origin which exhibited a potent capacity to produce GABA-based on thinlayer chromatography (TLC) and spectrophotometer. The $10 \mathrm{LAB}$ were cultivated in $10 \mathrm{ml}$ of MRS
Broth (Merck) having a glutamic acid concentration of $50 \mathrm{mM}$, a pH of 5 and incubated at $30^{\circ} \mathrm{C}$ for $72 \mathrm{~h}$. GABA content of the culture in the MRS Broth $(1 \mathrm{ml})$ was measured and used for high-performance liquid chromatography (HPLC) analysis.

\section{Optimization GABA production}

The optimization of GABA production was done to determine the influence of fermentation conditions such as $\mathrm{pH}$ (3.5-7), glutamic acid concentration $(0-600 \mathrm{mM})$, culture temperature $\left(30-42^{\circ} \mathrm{C}\right)$, incubation time $(0-108 \mathrm{~h}), 0.1-0.9 \%$ inoculum level $\left(10^{9} \mathrm{CFU} / \mathrm{ml}\right), 3 \%$ carbon $(\mathrm{w} / \mathrm{v})$, and $0.3 \%$ nitrogen $(\mathrm{w} / \mathrm{v})$ sources on GABA production by selected LAB. HPLC was used to measure the GABA content in the supernatants. Chemicals involved in this optimization are glutamic acid (Sigma-Aldrich, 99\%), glucose (Merck, pure), maltose (Merck, pure), sucrose (Merck, pure), $\mathrm{NH}_{4} \mathrm{NO}_{3}$ (Merck, pure), peptone (Merck, pure), skim milk (Intrasol), and yeast extract (Merck, pure).

\section{Identification and quantification of GABA by HPLC}

GABA produced after fermentation was measured using HPLC (Agilent Tech, Waldron, Germany). The HPLC had Hypersil ODS C18 reverse-phase column with $250 \mathrm{~mm}$ length, $5 \mu \mathrm{m}$ diameter, and $4.6 \mathrm{~mm}$ width. The culture broth $(100 \mu \mathrm{L})$ was sieved using a $0.22 \mu \mathrm{m}$ filter. Mobile phase A of the HPLC was filled with $10.254 \mathrm{~g}$ of $99 \%$ sodium acetate three hydrates (Sigma-Aldrich, USA). It was then dissolved in $900 \mathrm{~mL}$ of deionized water and $500 \mu \mathrm{L}$ trimethylamine (Merck). Glacial acetic was used to adjust the $\mathrm{pH}$ of the mobile phase A to 5.8. Acetonitrile (HPLC grade, Merck) and deionized water were the mobile phases $\mathrm{B}$ and $\mathrm{C}$, respectively. Phases were filtered through $0.22 \mu \mathrm{m}$ membrane filter, with an injection volume of $20 \mu \mathrm{L}$. The final compound was identified by the detector at $254 \mathrm{~nm}$. The quantity of GABA produced was computed by comparing the peak to the GABA standard.

\section{Results}

\section{Identification of selected LAB-producing GABA}

After qualitative and quantitative screening using TLC and HPLC, respectively [13], one isolate (isolate N5) showed the highest GABA production of $47.2 \mathrm{mM}$, compared to N1: 30.915; N2: 31.515; N3: 9.915; N4: 14.315; N6: 18.015; N7: 31.215; N8: 17.665; N9: 25.815, and N10: $7.815 \mathrm{mM}$. Isolate N5 was identified by PCR of $16 \mathrm{~S}$ rRNA gene sequences and a phylogenetic analysis was constructed for this isolate to compare it to homologous strains. N5 originated from fermented buffalo milk (dadih), had a sequence length of $1400 \mathrm{bp}$, and was identified as L. plantarum. Analysis of L. plantarum N5 using phylogenetic tree revealed similarities with $L$. plantarum strains NBRC 15891 (99\%) and JCM1149 (99\%). BLAST was then used to align the sequences to obtain LAB isolates of similar sequences to L. plantarum N5. Following 
kinship analysis, MEGA 7.0 (Society for Molecular Biology and Evolution, USA) was used to draw a phylogenetic tree for L. plantarum N5 and 25 homology LAB, as shown in Figure-1.

\section{Effect of temperature and initial pH}

Figure-2a reveals the effect of temperature $\left(30-42^{\circ} \mathrm{C}\right)$ on GABA yield. This was obtained using glutamic acid concentration of $50 \mathrm{mM}$, initial $\mathrm{pH}$ of 5 , and incubation time of $72 \mathrm{~h}$. Figure-2a shows that the optimum GABA production was at a temperature of $36^{\circ} \mathrm{C}$ and yielded $99.218 \mathrm{mM}$ of GABA. GABA yield decreased with increased temperature (beyond $36^{\circ} \mathrm{C}$ ). Figure- $2 b$ reveals the effect of initial $\mathrm{pH}$ on GABA yield. The initial $\mathrm{pH}$ profile was linear with GABA production from $\mathrm{pH} 3.5$ to 5.5 , whereas the optimum production of GABA was at $\mathrm{pH} 5.5$. Increased of $\mathrm{pH}$ from 6.0 to 7.0 decreased GABA production by L. plantarum N5. pH mainly regulates the biosynthesis of GABA and this process is species-dependent because LAB GAB enzyme has diverse characteristics.

\section{Effect of incubation time and L-glutamate concentration}

The incubation time and L-glutamate concentration on GABA production were done using an initial $\mathrm{pH}$ of 5.5 , culture temperature of $36^{\circ} \mathrm{C}$, and incubation time of $72 \mathrm{~h}$ in the culture medium. Figure-3a

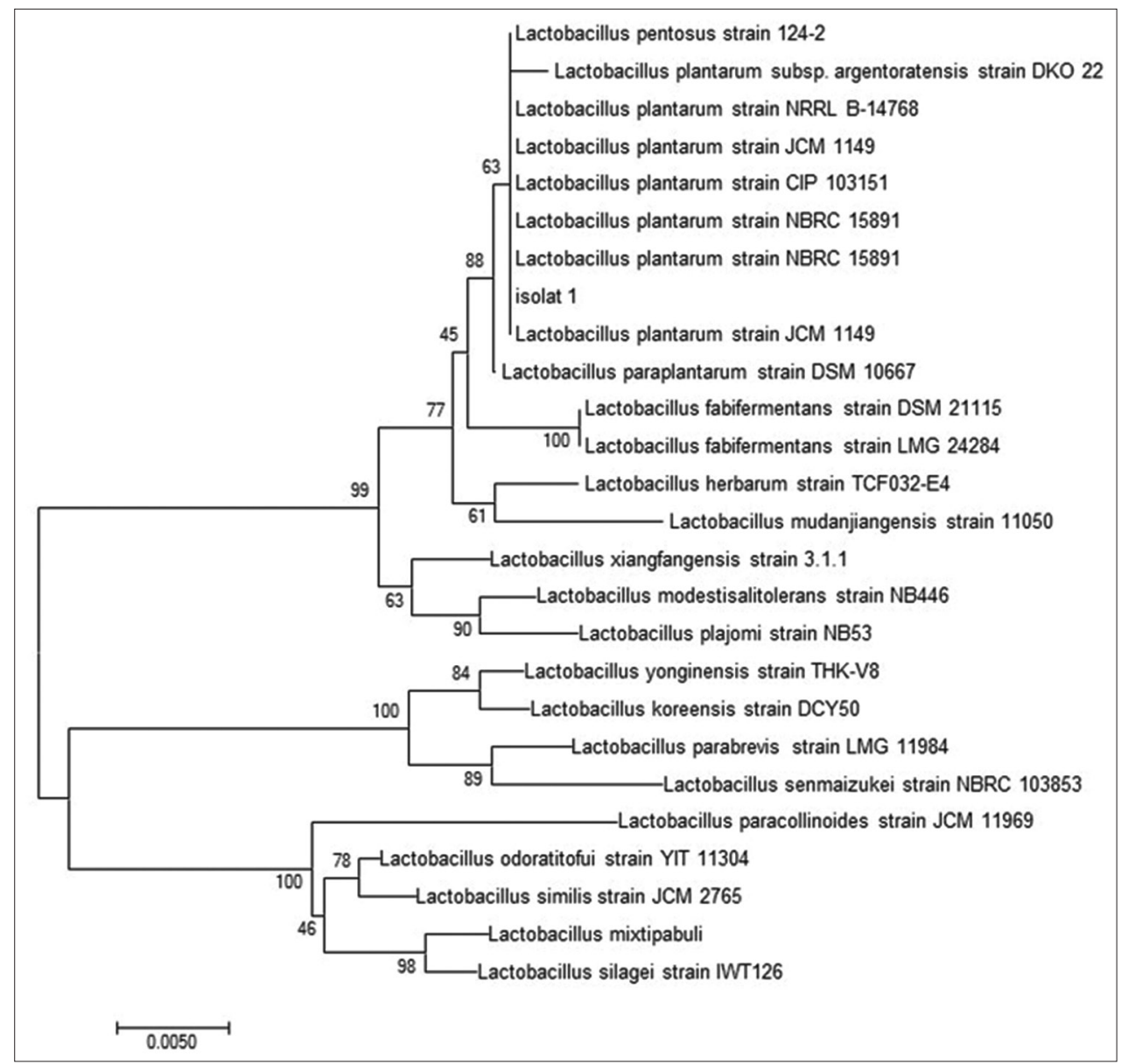

Figure-1: Phylogenetic tree of 16S rRNA gene of Lactobacillus plantarum N5 isolated from fermented buffalo milk (dadih) using neighbor-joining method MEGA 7.0.

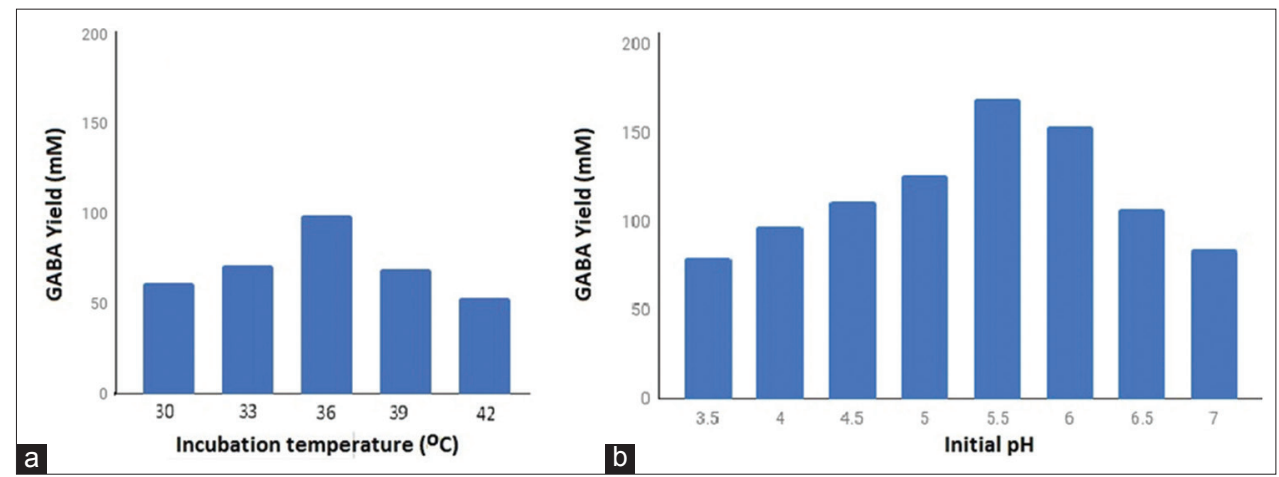

Figure-2: Effect of incubation temperature (a) and initial $\mathrm{pH}$ of medium (b) on $\mathrm{y}$-aminobutyric acid production by Lactobacillus plantarum N5. 
presents the effect of incubation time on the production of GABA, which shows that the optimum production of GABA was obtained at $84 \mathrm{~h}$, if incubation time is increased to $108 \mathrm{~h}$ a decrease in GABA occurs. Figure-3b shows that the optimum glutamic acid for highest GABA production was $500 \mathrm{mM}$, whereas increasing glutamic acid to $600 \mathrm{mM}$ decreased GABA production.

\section{Effect of carbon and nitrogen sources}

Carbon and nitrogen are important compounds required for the growth of L. plantarum N5 for optimum GABA production. Figures- $4 \mathrm{a}$ and $\mathrm{b}$ show that glucose and yeast extract are good sources of carbon and nitrogen, respectively, for high production of GABA.

\section{Discussion}

\section{Identification of selected isolate}

This study revealed that L. plantarum N5 was genetically closer (similarity of 99\%) to L. plantarum strain NBRC 15891 and L. plantarum strain JCM1149. In determining the genetic differences and variations in populations, genetic distances can be used [14]. This is calculated based on DNA sequences from the number of differences in the polymorphic gene loci of each population. Furthermore, phylogenetic analysis is important in sequence analysis [15]. Phylogenetics also provide relevant information required to understand changes that occur during evolution of different organisms.

\section{Effect of temperature and initial pH}

This is due to the fact that increasing temperature affect the growth rate of $L$. plantarum N5. Besides that, the enzyme produced in the medium such as glutamic acid decarboxylase (GAD) enzyme can influence the growth of L. plantarum N5. The function of the GAD enzyme is to convert glutamic acid to GABA, when the GAD activity is low, the resulting GABA will be low $\left(52.997 \mathrm{mM}\right.$ at $\left.42^{\circ} \mathrm{C}\right)$. Effects of temperature on the production of GABA have been reported by other researchers. The production of GABA by L. brevis RK03 was highest at a temperature of $30^{\circ} \mathrm{C}$ and yielded, $21.936 \mathrm{mg} / \mathrm{L}$ [16]. L. brevis NM101-1 and L. plantarum DSM749 had optimal temperature of $35^{\circ} \mathrm{C}$ for highest GABA yield of $168.58 \mathrm{mM}$ and $140.69 \mathrm{mM}$, respectively [17]. L. plantarum TajApis 362 produced the highest GABA at a temperature of $36^{\circ} \mathrm{C}$ [18]. Thermodynamic equilibrium of a reaction is affected by many factors including temperature. The right culture temperature and cell density are required for efficient conversion of glutamate to GABA. Besides, the incubation temperature, biocatalyst activity, and stability are essential factors that affect maximum GABA yield during fermentation.

Initial $\mathrm{pH}$ of the medium for fermentation is an important condition in the production of GABA and



Figure-3: Effect of incubation time (a) and L-glutamate concentration (b) on $\mathrm{Y}$-aminobutyric acid production by Lactobacillus plantarum N5.

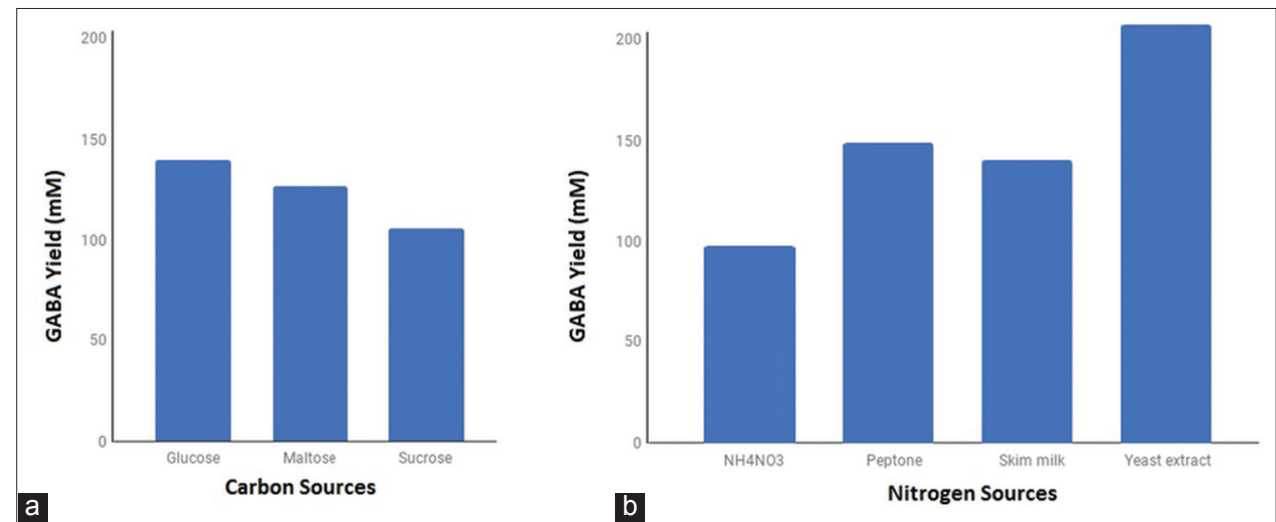

Figure-4: Effect of carbon (a) and nitrogen (b) sources on the $\mathrm{Y}$-aminobutyric acid production by Lactobacillus plantarum N5. 
has a relationship with GAD activity. Optimum $\mathrm{pH}$ is required for maintaining the activities of $\mathrm{GAD}$, an enzyme responsible for GABA synthesis [11]. Low or high $\mathrm{pH}$ may lead to partial loss of GAD activities. In this study, the highest GABA production was obtained at a $\mathrm{pH}$ of 5.5. Yip et al. [19] and Fatemi et al. [20] showed that enhancing GABA production in an acidic condition is closely linked to the characteristics of GAD which shows enhanced activity and stability when hydrogen ions are present.

\section{Effect of incubation time and L-glutamate concentration}

Figure-3a shows that GABA production increased rapidly during $60-84 \mathrm{~h}$ of incubation, optimum at $84 \mathrm{~h}$, and decreased after $84 \mathrm{~h}$. Biosynthesis of GABA production might be attributed to inhibitory effects of glutamic acid and the concentration of GABA [21-23]. In Figure-3a, it can also be seen that the transformation of glutamic acid to GABA by GAD follows the growth pattern of L. plantarum N5, at a fermentation time of 12-24 $\mathrm{h}$ for the lag phase, 36-84 $\mathrm{h}$ for the exponential phase, and 96-108 $\mathrm{h}$ for the stationary phase. In the stationary phase, lower GABA production caused decreased in the nutrients needed for growth and enzyme production. Figure-3b shows a higher GABA yield at $500 \mathrm{mM}$ of glutamic acid when the concentration was increased to $600 \mathrm{mM}$, the production of GABA decreased. Li et al. [10] also found that the production of GABA was suppressed when glutamic acid concentration was increased.

\section{Effect of carbon and nitrogen sources}

Figures- $4 \mathrm{a}$ and $\mathrm{b}$ show the effects of carbon and nitrogen sources on the production of GABA by selected LAB. In Figure-4a, MRS Broth was used to investigate the effects of carbon sources on the production of GABA by L. plantarum. The MRS Broth contained $3 \%$ carbon $(\mathrm{w} / \mathrm{v})$ and $500 \mathrm{mM} \mathrm{L}$-glutamic acid. There were remarkable differences in GABA production due to the addition of carbon of different sources. Glucose was found to be the best carbon source for the production of GABA $(139.843 \mathrm{mM})$ followed by maltose $(126.649 \mathrm{mM})$ and sucrose $(106.033 \mathrm{mM})$. Similarly to this study, glucose was found to be the best carbon source for the production of GABA [22,24].

With regard to sources of nitrogen, yeast extract was found to be the best for the production of GABA (211.69 $\mathrm{mM})$, followed by peptone $(151.698 \mathrm{mM})$, skim milk (142.636 mM), and $\mathrm{NH}_{4} \mathrm{NO}_{3}(99.216 \mathrm{mM})$, which might be attributed to their compositions in the MRS Broth. Researchers have shown that diverse carbon sources can be optimized for GABA production such as 3\% sucrose for $L$. brevis $340 \mathrm{G}, 4 \%$ sucrose for Lactobacillus sakei B2-16, and 1\% glucose for $L$. buchneri MS [22,25,26].

\section{Conclusion}

The conditions optimum for maximum production of GABA by L. plantarum N5 were an initial $\mathrm{pH}$ of 5.5, glutamic acid concentration of $500 \mathrm{mM}$, yeast extract as nitrogen source, glucose as carbon source, and incubation temperature and time of $36^{\circ} \mathrm{C}$ and $84 \mathrm{~h}$, respectively.

\section{Authors' Contributions}

$\mathrm{HH}, \mathrm{NN}$, and YM collected data and wrote the manuscript. YM designed the study. FA and $\mathrm{NH}$ reviewed and updated the manuscript. All authors read and approved the final manuscript.

\section{Acknowledgments}

The authors are grateful to the Ministry of Research, Technology and Higher Education of Indonesia for funding the BOPTN Andalas University Grants through Research Cluster Grant No: 60/ UN.16.17/HGB/LPPM/2017 and the assistance by World Class Professor Program Scheme-B No. $123.57 / \mathrm{D} 2.3 / \mathrm{KP} / 2018$.

\section{Competing Interests}

The authors declare that they have no competing interests.

\section{Publisher's Note}

Veterinary World remains neutral with regard to jurisdictional claims in published institutional affiliation.

\section{References}

1. Putra, A.A., Marlida, Y., Khasrad, Azhike, S.Y.D. and Wulandari, R. (2011) Development and efforts of developing curd: A review of traditional Minangkabau fermented milk. J. Peternakan, 13(3): 159-170.

2. Farhana, F. (2011) Production of Fermented Cow's Milk Using Isolated Dominant Lactic Acid Bacteria and Yeasts Obtained from Dadih's Fermentation Process. Microbiology School of Life Sciences and Technology. Bandung Institute of Technology, Indonesia.

3. Surono, I.S. (2004) Probiotics for Fermented Milk and Health, the Indonesian Food and Beverage Entrepreneurs Foundation (YAPMMI). TRICK Jakarta, Indonesia.

4. Pato, U. (2003) The potential of lactic acid bacteria isolated from curd to reduce the risk of cancer. J. Nat. Indonesia, 5(2): 162-166.

5. Sunaryanto, R. and Marwoto, B. (2013) Isolation, identification, and characterization of lactic acid bacteria from buffalo milk curd. J. Sains Teknologi Indonesia, 14(3): 228-233.

6. Usmiati, S., Broto, W. and Setiyanto, H. (2011) Characteristics of cow milk curd using a starter of probiotic bacteria. J. Ilmu Ternak Vet., 16(2): 141-153.

7. Dhakal, R., Bajpai, V.K. and Baek, K.H. (2012) Production of GABA $(\gamma$-aminobutyric acid) by microorganisms: A review. Braz. J. Microbiol., 43(4): 1230-1241.

8. Hagi, T., Kobayashi, M. and Nomura, M. (2016) Metabolome analysis of milk fermented by $\gamma$-aminobutyric acid-producing Lactococcus lactis. J. Dairy Sci., 99(2): 994-1001.

9. Xie, L.J., Xie, X.Z.I., Zhou, Y.W.I., Liang, C.I., Jiang, Y.Y.I. and Chen, Z. (2016) Effect of heat stress on the expression of GABA receptor $\mathrm{mRNA}$ in the HPG axis of Wenchang chickens. Braz. J. Poul. Sci., 18(2): 277-282.

10. Li, H., Qiu, T., Gao, D. and Cao, Y. (2010) Medium optimization for production of gamma-aminobutyric acid by Lactobacillus brevis NCL912. Amino Acid, 38(5): 1439-1445.

11. Komatsuzaki, N., Nakamura, T., Kimura, T. and Shima, J. (2008) Characterization of glutamate decarboxylase from a 
High $\gamma$-aminobutyric acid (GABA)-producer, Lactobacillus paracasei. Biosci. Biotech. Biochem., 72(2): 278-285.

12. Yang, S.Y., Lu, F.X., Lu, Z.X., Bie, X.M., Jiao, Y., Sun, L.J. and $\mathrm{Yu}, \mathrm{B}$. (2008) Production of gamma-aminobutyric acid by Streptococcus salivarius subsp. Thermophilus Y2 under submerged fermentation. Amino Acids, 34(3): 473-478.

13. Marlida, Y., Hernetis and Nurmiati. (2016) Dadih for glutamic acid production as precursor of $\gamma$-aminobutyric acid (GABA) induced heat stress in broiler. Int. J. PharmTech Res., 9(12): 536-542.

14. Brinkman, F. and Leipe, D. (2001) Phylogenetic analysis. In: Baxevanis, A.D. and Ouellette B.F.F., editors. Bioinformatics: A practical guide to the analysis of gene and protein. John Willey and Sons, New York. p323-358.

15. Roy, M., Kumar, R., Ramteke, M. and Sit, A. (2018) Identification of lipase producing fungus isolated from dairy waste contaminated soil and optimization of culture conditions for lipase production by the isolated fungus. $J$. Microb. Biotech. Food Sci., 8(1): 698-704.

16. Wu, C.H., Hsueh, Y.H., Kuo, J. and Liu, S.J. (2018) Characterization of a potential probiotic Lactobacillus brevis RK03 and efficient production of $\gamma$-aminobutyric acid in batch fermentation. Int. J. Mol. Sci., 19(1): 1-16.

17. Gomaa, E.Z. (2015) Enhancement of $\gamma$-aminobutyric acid production by co-culturing of two lactobacilli strains. Asian J. Biotechnol., 7(3): 108-118.

18. Tajabadi, N., Ebrahimpour, A., Baradaran, A., Rahim, R.A., Mahyudin, N.A., Manap, M.Y.A., Bakar, F.A. and Saari, N. (2015) Optimization of $\gamma$-aminobutyric acid production by Lactobacillus plantarum Taj-Apis362 from honeybees. Mol., 20(2): 6654-6669.

19. Yip, J., Soghomonian, J.J. and Blatt, G.J. (2007) Decreased GAD67 mRNA levels in cerebellar purkinje cells in autism: Pathophysiological implications. Acta Neuropath., 113(5): 559-568.

20. Fatemi, S.H., Folsom, T.D., Kneeland, R.E. and Liesch, S.B. (2011) Metabotropic glutamate receptor 5 upregulation in children with autism is associated with underexpression of both Fragile $\mathrm{X}$ mental retardation protein and GABAA receptor beta 3 in adults with autism. Anat. Rec., 294(10): 1635-1645.

21. Lim, H.S., Cha, I., Lee, H. and Seo, M.J. (2016) Optimization of $\gamma$-aminobutyric acid production by Enterococcus faecium JK29 isolated from traditional fermented foods. Microbiol. Biotechnol. Lett., 44(1): 26-33.

22. Cho, Y.R., Chang, J.Y. and Chang, H.C. (2007) Production of gamma-aminobutyric acid (GABA) by Lactobacillus buchneri isolated from kimchi and its neuroprotective effect on neuronal cells. J. Microbiol. Biotechnol., 17(1): 104-109.

23. Kim, J.Y., Lee, M.Y., Ji G.E., Lee, Y.S. and Hwang, K.T. (2009) Production of $\gamma$-aminobutyric acid in black raspberry juice during fermentation by Lactobacillus brevis gaba100. Int. J. Food Microbiol., 130(1): 12-16.

24. Baritugo, K.A., Kim, H.T., David, Y., Khang, T.U., Hyun, S.M., Kang, K.H., Yu, J.H., Choi, J.H., Song, J.J., Joo, J.C. and Park, S.J. (2018) Enhanced production of gamma-aminobutyrate (GABA) in recombinant Corynebacterium glutamicum Strains from empty fruit bunch biosugar solution. Microb. Cell Fact.,17(1), 129.

25. Kook, M.C., Seo, M.J., Cheigh, C.I., Pyun, Y.R., Cho, S.C. and Park, H. (2010) Enhanced production of gamma-aminobutyric acid using rice bran extracts by Lactobacillus sakei B2-16. J. Microb. Biotechnol., 20(4): 763-766.

26. Seo, M.J., Lee, J.Y., Nam, Y.D., Lee, S.Y., Park, S.L. and Yi, S.H. (2013) Production of $\gamma$-aminobutyric acid by Lactobacillus brevis $340 \mathrm{G}$ isolated from kimchi and its application to skim milk. Food Eng. Prog., 17(4):418-423.

\section{$* * * * * * * *$}

